\title{
Tilia trees: toxic or valuable resources for pollinators?
}

\author{
Anne-Laure JACQUEMART ${ }^{1}$, Laura MoqueT ${ }^{1}$, Pierre OUVRARD ${ }^{1}$, \\ Joëlle Quetin-LeCLERCQ ${ }^{2}$, Marie-France HÉRENT ${ }^{2}$, Muriel QuineT ${ }^{1}$ \\ ${ }^{1}$ Earth and Life Institute, Université catholique de Louvain, Croix du Sud 2, Box L7 05.14, 1348, Louvain-la-Neuve, \\ Belgium \\ ${ }^{2}$ Louvain Drug Research Institute, Université catholique de Louvain, Avenue Mounier 72, Box B1.72.03, 1200, \\ Woluwe-Saint-Lambert, Belgium
}

Received 24 August 2017 - Revised 2 January 2018 - Accepted 26 April 2018

\begin{abstract}
To investigate whether Tilia trees are poisonous or valuable resources for bee visitors, we determined the nectar and pollen quantities and composition of the four main Tilia species planted in Western Europe (T. cordata, T. platyphyllos, T. tomentosa, and T. × europaea ). We developed a new method to detect nicotine in nectars. We observed insect visitor diversity and abundance. We also assessed bumblebee death when individuals were only fed with Tilia flowers. No traces of mannose or nicotine, incriminated in the Tilia toxicity, have been detected in the nectars of the studied species. Huge numbers of insect visitors, mainly bees and syrphids, visited the trees which offer large numbers of flowers, plenty of sugar rich nectar, and protein-rich pollen. Bumblebees only fed with Tilia flowers did not present any particular mortality. We discuss the different hypotheses of the supposed toxicity and propose future research to solve this debate.
\end{abstract}

\section{linden trees / Tilia tomentosa / nicotine / mannose / bees / nectar / pollen}

\section{INTRODUCTION}

Pollinator decline is a worldwide phenomenon and is commonly attributed to anthropogenic causes such as habitat destruction and fragmentation (including urbanization), floral resource shortages, application of pesticides, introduction of parasites, or biological invasions (Goulson et al. 2015). Urbanization represents a major proposed cause of insect decline, particularly through alteration of food resources and nesting sites (McKinney 2008; Bates et al. 2011).

However, in cities, mass flowering trees that represent huge floral resources during several weeks

Electronic supplementary material The online version of this article (https://doi.org/10.1007/s13592-018-0581-3) contains supplementary material, which is available to authorized users.

Corresponding author: A. Jacquemart, anne-

laure.jacquemart@uclouvain.be

Handling editor: Bernd Grunewald may constitute valuable food for generalist insects (Hunter and Hunter 2008; Somme et al. 2016).

In this context, different species of linden or lime trees (Tilia spp., Malvaceae) are often planted as valued park trees along avenues and roads as they offer good compromises in urban plantings (Pawlikowski 2010; WeryszkoChmielewska and Sadowka 2010). Tilia spp., with about 30 species, are deciduous trees from the temperate zones of the Northern Hemisphere (Pigott 2012; Ivanov et al. 2014). Besides the common names given to Tilia species, another widely used name in Europe is "bee tree" and Tilia trees are considered of high apicultural value (Anderson 1976). Bees collect predominantly pollen (Free 1970; Illies 2016) even if they also visit flowers for nectar (Weryszko-Chmielewska and Sadowka 2010; Pawlikowski 2010; Gašić et al. 2014; Illies 2016).

Two native species are present in northwestern Europe, Tilia cordata Mill., the smallleaved lime, and Tilia platyphyllos Scop., the 
large-leaved lime (Tutin et al. 1968; Radoglou et al. 2009). They form a natural inter-specific hybrid, $T$. $\times$ europaea L., the common lime. Tilia tomentosa Moench, the silver lime, grows only in southeastern Europe (Tutin et al. 1968). All species flower profusely in June and July; their blooming periods overlap to a large extent (Anderson 1976). Tilia platyphyllos is the first, and $T$. tomentosa is the last species to flower. This flowering at different times can provide forage for insects over a period of 6 weeks (Weryszko-Chmielewska and Sadowka 2010). The numerous fragrant pale yellow-green open flowers are organized in cymes of 4 to 15 flowers (Tutin et al. 1968; Anderson 1976). They have numerous anthers and offer easily accessible nectar to generalist insects with short tongues, especially flies, syrphids, and bees (Anderson 1976; Pigott 1991). Bees are the main visitors and pollinators, even if other generalist insects are also abundantly observed on Tilia trees (Knuth 1908; Anderson 1976; Pigott 1991). Due to their numbers, their morphology, and their behavior, they contact reproductive organs and insure pollination combining pollen removal from anthers, transport, and deposition on stigmas (Anderson 1976). Tilia species require insect pollination, spontaneous selfpollination being unlikely due to herkogamy and protandry of flowers (Anderson 1976; Illies 2016).

For several years, the toxicity of Tilia tree species for insect visitors is under debate as dead bees have been observed under the trees in different countries (Geissler and Steche 1962; Madel 1977; Mühlen et al. 1992, 1994; Baal et al. 1994; Surholt and Baal 1995; Illies and Mühlen 2007; Pawlikowski 2010; Illies 2016; Koch and Stevenson 2017). More frequent deaths were observed among bumblebees than among honeybees (Mühlen et al. 1994; Pawlikowski 2010; Illies 2016; Argoti 2016).

Two main hypotheses have been proposed to explain how Tilia trees may cause bees to die. The first hypothesis posits that flowers of Tilia are poisonous (Crane 1977; Argoti 2016; VKM 2017). Nectar is the principal source of carbohydrates for most flower visiting insects (Baker 1977; Nicolson 2011). Certain sugars, which disturb carbohydrate metabolism in bees (Arnold et al. 1974), have been incriminated in the toxicity of Tilia trees and specifically mannose (Crane 1977; Madel 1977; Argoti 2016, but see Baal et al. 1994 and Krasenbrink et al. 1994). Mannose has been detected in nectar of other plant species such as Tordylium apulum (Apiaceae) or Cistus salvifolius (Cistaceae) (Petanidou 2005). Nectar can also contain low concentrations of other potentially toxic compounds, such as alkaloids, phenolics, or other compounds (Tiedeken et al. 2014). Particularly, alkaloids are highly toxic to bees across a wide range of concentrations (Singaravelan et al. 2006). One alkaloid, nicotine, has been incriminated to explain the toxicity of Tilia species. Nicotine is toxic for adult honeybee workers (Baracchi et al. 2015) at LD50 concentration of $2000 \mathrm{ppm}(12.3 \mathrm{mmol} / \mathrm{L})$ (Detzel and Wink 1993) while a concentration of $50 \mathrm{ppm}$ already affects larval survival (Singaravelan et al. 2006). Regarding bumblebees, Tiedeken et al. (2014) reported that $16.2 \mathrm{ppm}(0.1 \mathrm{mmol} /$ L) of nicotine is deterrent for Bombus terrestris even if no change in the survival of individuals has been detected. Nicotine has been detected, and its concentration varied from 0.1 to $3.0 \mathrm{ng} / \mu \mathrm{L}$ in nectar of two genera Nicotiana and Tilia species (Kessler et al. 2010; Tadmor-Melamed et al. 2004; Baracchi et al. 2015).

Besides toxicity of floral resources, a second hypothesis claims that Tilia flowers do not contain sufficient nectar to feed insect visitors. In this case, visitors starve to death (Mühlen et al. 1994; Baal et al. 1994; Surholt and Baal 1995; Illies 2016; VKM 2017; Koch and Stevenson 2017). Nectar content in Tilia flowers is effectively highly variable in time with a decrease in nectar volume throughout the day and towards the end of the season (Illies 2016).

Our objective was to detect whether Tilia species are toxic for their main bee pollinators and to compare the concentration of the incriminated toxic compounds, mannose and nicotine, among the principal planted Tilia species in Western Europe, T. cordata, T. platyphyllos, their hybrid T. $\times$ europaea, and the most controversial introduced T. tomentosa .

Here we analyzed nectar and pollen composition, including the presence of mannose and 
nicotine in nectar. We developed a new method to detect nicotine in nectars. We also observed the behavior and survival of bees foraging on Tilia trees.

We addressed the following questions: (i) Do the different Tilia species offer nectar and pollen in similar quantities and of similar composition? (ii) Do the nectars of Tilia species contain mannose, other minor toxic sugars and/or nicotine? (iii) Do the different Tilia species attract the same insect visitor species and with similar relative abundances? (iv) Do bumblebees that are exclusively fed on Tilia nectar present an increased mortality?

\section{MATERIALS AND METHODS}

\subsection{Plant material}

We sampled four Tilia species planted in Louvain-la-Neuve, Belgium: Tilia cordata, T. platyphyllos, their hybrid T. $\times$ europaea, and T. tomentosa. Tilia trees were sampled in 2016 and 2017 along Avenue Baudouin 1er and in different parks at the University Campus $\left(50^{\circ}\right.$ $39^{\prime} 58^{\prime \prime} \mathrm{N}$; 40 37' 9" E).

Tree height, trunk diameter, crown volume, and the number of flowers per tree were estimated on three trees per species. The number of flowers per tree was estimated by counting the open flowers on three flowering parts of the crow (known volume) per tree and was expressed as the number of flowers per cubic meter of crown.

A total of 15 flower buds per species were dissected ( 5 per tree from 3 trees) to assess the number of anthers and of pollen grains per flower. Pollen grains were counted for one stamen per flower. The anthers were individually crushed in a microcentrifuge tube, containing $200 \mu \mathrm{L}$ of Alexander's stain. They were then mixed and sonicated to disperse the pollen grains in the solution. The number of pollen grains was counted in three subsamples of $4 \mu \mathrm{L}$ per anther under light microscopy (Eclipse E400; Nikon, Amsterdam, The Netherlands). Numbers of pollen grains per flower were obtained by multiplying the numbers of pollen grains per anther by the numbers of anthers of a flower.

\subsection{Pollen composition}

\subsubsection{Pollen sampling}

At the peak of flowering (i.e., late June to midJuly), branches with unopened flower buds were harvested from five trees per species. Branches, placed in tap water, were kept for one night at room temperature (approx. $20^{\circ} \mathrm{C}$ ) in the lab. On the next morning, stamens were extracted from newly opened flowers. Stamens were stored at $20^{\circ} \mathrm{C}$ and subsequently dried at room temperature for $12 \mathrm{~h}$ before pollen was removed using a sieve (Sieve 3", Brass-Stainless, Full Height, $80 \mu \mathrm{m}$ ). Pure pollen samples were pooled to obtain $200 \mathrm{mg}$ samples sufficient for analyses and stored at $20{ }^{\circ} \mathrm{C}$ until use.

\subsubsection{Chemical analyses}

Chemical analyses were performed in triplicate, as in other recent studies (Weiner et al. 2010; Vanderplanck et al. 2011, 2014; Somme et al. 2015; Villette et al. 2015).

The polypeptide content (molecular weight $>$ $10,000 \mathrm{Da}$ ) was quantified from $5 \mathrm{mg}$ dry pollen of each species (Vanderplanck et al. 2014). The polypeptide purification protocol combined washes and a phenol/sodium dodecylsulfate extraction. The quantification of total polypeptide content was performed using the bicinchoninic acid (BCA) Protein Assay Kit (Pierce, Thermo Scientific) according to manufacturer instructions and using bovine serum albumin (BSA) for standard curve.

The amino acid concentrations were quantified from $3 \mathrm{mg}$ dry pollen of each species (Vanderplanck et al. 2014). Total and free amino acids were extracted separately and measured by an ion-exchange chromatography (Biochrom 20 plus amino-acid analyzer). For both extractions, norleucine was used as the internal standard.

The phytosterol content was quantified from $15 \mathrm{mg}$ dry pollen of each species (Vanderplanck et al. 2011). After extraction and derivatization of the sterols into their respective trimethylsilyl ethers, these were separated by gas-liquid chromatography. The total phytosterol content was determined by considering all quantifiable peaks 
of sterols that eluted between cholesterol and betulin (internal standard). Identifications were achieved by comparing the relative retention times $(\beta$-sitosterol-TMS $=1.00)$ with those of sunflower oil reference.

\subsection{Chemical composition of nectar}

\subsubsection{Nectar sampling}

Branches with unopened flower buds were harvested from five trees per species at the same time that pollen was collected. Nectar collection from flowers on the branches was conducted in the lab (Somme et al. 2016). Branches, placed in tap water, were kept for one night at room temperature (approx. $20^{\circ} \mathrm{C}$ ). On the next morning, nectar was extracted from newly opened flowers. This method avoids differences due to climatic conditions (temperature and relative humidity) in the field and previous visits to flowers by insects. For each tree species, nectar was collected from at least 50 (depending on the nectar volume) newly opened flowers with glass capillary tubes of $5 \mu \mathrm{L}$ (Hirschmann®Laborgerate, Eberstadt, Germany). The nectar volume was estimated by measuring the length of the nectar column in the capillary tube. Nectar samples were stored at $-80^{\circ} \mathrm{C}$ until chemical analyses.

\subsubsection{Sugar composition analyses}

The main sugar (sucrose, fructose, and glucose) and minor sugar (galactose, mannose, myoinositol, raffinose, and kestose) concentrations were determined for each species in triplicate, from respectively 3 and $10 \mu \mathrm{L}$ of nectar. After oxymation, sugar concentrations were determined by gas chromatography, with a PerkinElmer Autosystem XL equipped with a split injector $(1 / 20$; injection volume of $2 \mu \mathrm{L})$, a detector FID using a column Chrompack WCOT CP-SIK5

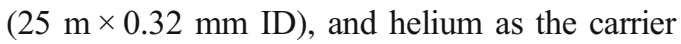
gas (flow of $1 \mathrm{~mL} / \mathrm{min}$ ). The injector and detector temperatures were maintained at 270 and $350{ }^{\circ} \mathrm{C}$, respectively. The total sugar content of nectar per flower (mg) was calculated by multiplying the volume of nectar $(\mu \mathrm{L})$ by the total sugar concentration $(\mathrm{mg} / \mu \mathrm{L})$.

\subsubsection{Nectar nicotine analyses}

We developed a new method for nicotine detection in nectars (see Supplemental data for details). Nicotine purifications from nectar were performed by solid-phase extraction (SPE) on the weak cation exchanger cartridge Strata $\mathrm{X}-\mathrm{CW}$ $33 \mu \mathrm{m}(30 \mathrm{mg} / 3 \mathrm{~mL})$ from Phenomenex. Nicotine was then quantified by HPLC-MS/MS (Abdallah et al. 2016). The protocols followed the recommendations of EMEA ( 2011).

We prepared dilutions of Tilia nectars on the basis of a potential nicotine concentration of $10 \mu \mathrm{M}(1620 \mathrm{ng} / \mathrm{mL})$, concentration detected by bumblebees (Tiedeken et al. 2014). We diluted the nectars in order to obtain a potential final concentration of $6.48 \mathrm{ng} / \mathrm{mL}$, concentration in our calibration range. Internal standard (D4-nicotin) was added at a concentration of $200 \mathrm{ng} / \mathrm{mL}$ before SPE, its final concentration reaching $20 \mathrm{ng} / \mathrm{mL}$ in the injected solution. The deposited sample volume on the SPE cartridges was $500 \mu \mathrm{L}$.

\subsection{Insect visitor behavior}

\subsubsection{Insect visitor observations on the trees}

In 2016, insect visitors were observed on planted Tilia trees at Louvain-la-Neuve during observation periods of $15 \mathrm{~min}$ (a total of 70 periods), during several sunny days per species (beginning with $T$. platyphyllos in mid-June and ending with $T$. tomentosa in mid-July). The numbers of open flowers were assessed before any observation. All visitors were recorded and considered as pollinators when contacting the reproductive organs of a flower. As bumblebee species are not distinguishable in the field due to their similar morphology and color, we identified them in the field to morphotypes. Subsamples of bumblebee (Hymenoptera) and syrphid (Diptera) individuals were collected for precise identification in the lab.

One white sheet of $10 \mathrm{~m}^{2}$ was deposited during 2 days and $10 \mathrm{~h}$ per day under one tree per species in full bloom to collect dead insects. After collection, insects were stored at $-20{ }^{\circ} \mathrm{C}$ until identification to species level in the lab. 


\subsubsection{Bumblebee behavior and survival under controlled conditions}

In 2017, we tested the survival of bumblebees fed only with flowers of Tilia in three independent experiments. Bunches of flowered branches of $T$. cordata and T. tomentosa were harvested on a minimum of five trees per species and placed in tap water under three individual mosquito nets $(190 \times 125 \times 125 \mathrm{~cm}$, Outillage de Saint Etienne, France) per Tilia species. Ten naïve worker bumblebees were placed under each net with the flowered branches for 1 week. For the three experiments, each set of bumblebees was sampled from a different hive of Bombus terrestris (three hives, Biobest, Westerloo, Belgium). Branches were replaced three times a week. We observed the survival of the bumblebees and their behavior twice a day (10:00 am and 04:00 pm). A control was conducted under the same conditions, with unflowered branches of Tilia. To compensate the absence of flowers in control conditions, "mix flower" pollen (François Dequit, Meris, France) and nectar substitute (Biogluc solution, Biobest, Westerloo, Belgium) were provided ad libitum.

\subsection{Data analyses}

Prior to analyses of variance (ANOVA), homoscedasticity and normality were checked using Bartlett and Shapiro-Wilk tests, respectively. One-way and two-way analyses of variance (ANOVA) were performed with SAS Enterprise Guide 7.1. Post-hoc analyses were performed using Tukey's tests.

Data are presented as means \pm standard deviations.

\section{RESULTS}

\subsection{Quantity of floral resources}

The number of flowers per tree differed with $T$. $\times$ europaea and T. tomentosa producing more flowers per cubic meter $(28,200 \pm 17,100$ and $30,100 \pm 7000$, respectively) than $T$. cordata $(10,200 \pm 7800)$ and T. platyphyllos $(10,000 \pm$ 4700; $F(3,32)=10.33 ; p<0.0001)$.
Tilia tomentosa produced also a higher quantity of floral resources in comparison with the three other species (Figure 1a, b). The numbers of pollen grains per flower ranged from $2716 \pm$ $450 \times 10^{3}$ for $T$. tomentosa to $1647 \pm 244 \times 10^{3}$ for $T$. cordata $(F(3,32)=13.42 ; p$ value < 0.0001 ; Figure 1a). The volumes of nectar per flower of T. tomentosa and T. cordata were twice higher than those of $T$. platyphyllos and $T . \times$ europaea $(F(3,56)=125.93 ; p$ value $<0.0001$; Figure 1b).

\subsection{Chemical composition of floral resources}

\subsubsection{Pollen composition}

The total content of sterols in the pollen did not differ significantly $(F(3,6)=0.12 ; p$ value $=$ $0.9426)$ and averaged $4.5 \pm 0.4 \mu \mathrm{g} / \mathrm{mg}$ (Figure 1c). However, the composition differed greatly among species (Table I). Pollen of T. platyphyllos was characterized by a high concentration of D7-avenasterol and a low concentration of 24 methylencholesterol in comparison with other studied species (Table I).

Tilia platyphyllos pollen had the highest concentrations in both total $(322.1 \pm 6.8 \mu \mathrm{g} / \mathrm{mg}$, $F(3,8)=82.84 ; p$ value $<0.0001)$ and essential amino acids $(136.4 \pm 3.6 \mu \mathrm{g} / \mathrm{mg}, F(3,8)=36.13$; $p$ value $<0.0001)$ whereas $T$. tomentosa pollen presented the lowest values $(209.3 \pm 5.6 \mu \mathrm{g} / \mathrm{mg}$ and $100.3 \pm 2.8 \mu \mathrm{g} / \mathrm{mg}$, respectively; Figure 1d). The concentrations in the different amino acids differed among species with $T$. platyphyllos showing the highest concentrations in all amino acids at the exception of cysteine, methionine and phenylalanine (Table I). The concentrations of polypeptides ranged from $33.4 \pm 1.9 \mu \mathrm{g} / \mathrm{mg}$ in $T$. $\times$ europaea to $21.0 \pm 2.8 \mu \mathrm{g} / \mathrm{mg}$ in $T$. cordata $(F(3,14)=5.14 ; p$ value $=0.0133 ;$ Figure 1e $)$.

\subsubsection{Nectar composition}

Sugar concentrationsTilia tomentosa nectar sugar concentration was twice higher than Tilia platyphyllos and $T . \times$ europaea nectar and four times higher than $T$. cordata (Figure 1f). This difference was mainly due to sucrose concentration 

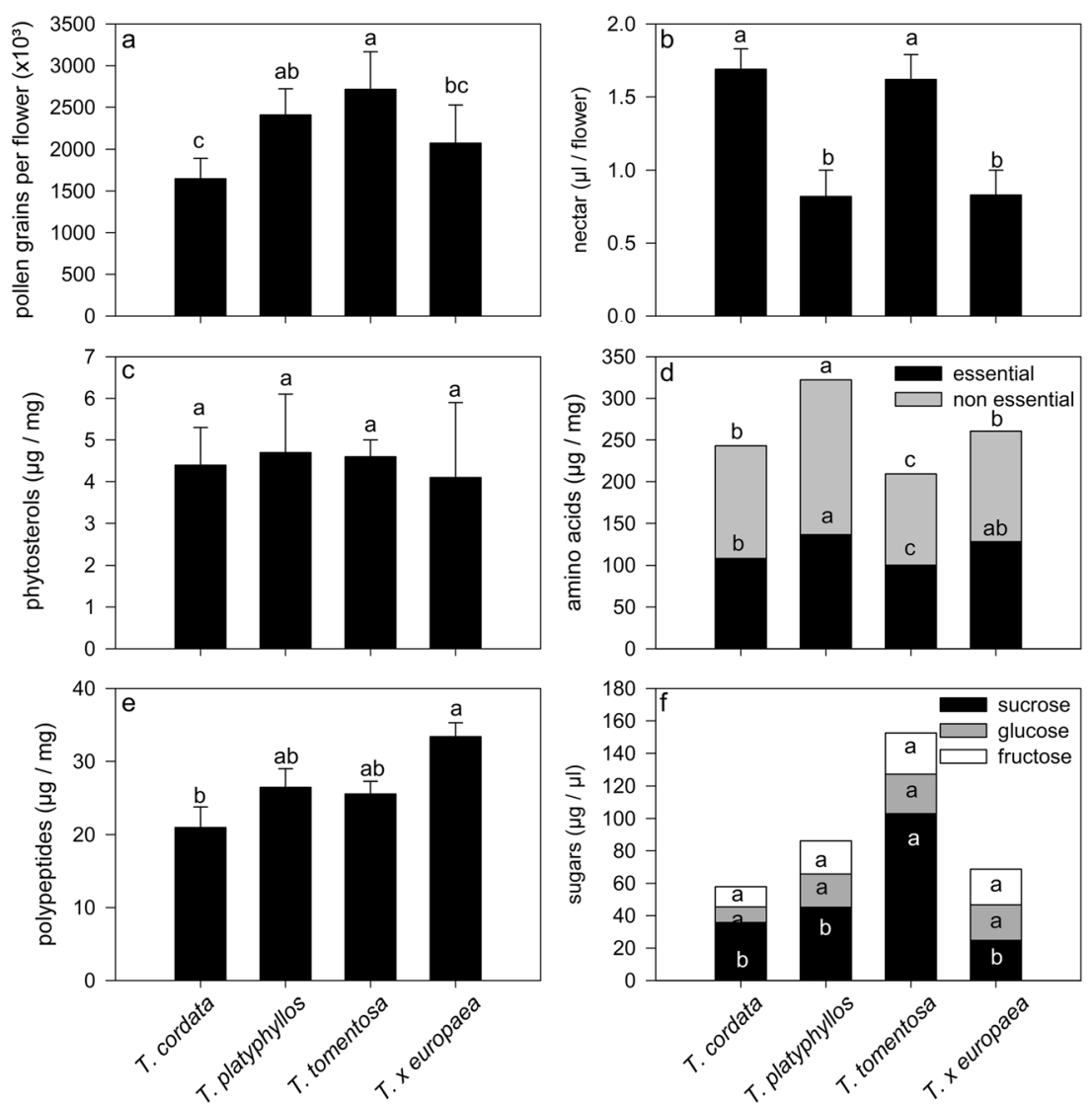

Figure 1. Pollen and nectar resources of the four studied Tilia species: pollen grains per flower $\left(\times 10^{3}, \mathbf{a}\right)$; nectar volume ( $\mu \mathrm{L} /$ flower, b); phytosterol (c), amino acid (d), and polypeptide (e) concentrations $(\mu \mathrm{g} / \mathrm{mg})$ in pollen; sugar concentration in nectar $(\mu \mathrm{g} / \mu \mathrm{L}, \mathbf{f})$. Different letters indicate significant differences among species.

$(F(3,6)=7.04 ; p$ value $=0.0161)$. The ratios sucrose/hexoses were significantly different among Tilia species, ranging from sucrose dominant nectar in T. tomentosa to hexose dominant nectar in $T . \times$ europaea (Figure 1f).

No trace of mannose $(<1.44 \mathrm{ng} / \mu \mathrm{L})$ was detected whereas traces of galactose, myoinositol, and raffinose were detected in some of our studied Tilia species (Table II).

Nicotine We successfully developed a new method to detect nicotine in nectar, a high sugar rich solution, by SPE-HPLC-MS/MS (see Supplemental data). The extraction recovery was considered as very good with a mean of $95.32 \%$, which was taken into account in all further concentration calculations (Table III).
The subsequent analyses of the collected Tilia nectars did not allow us to detect any trace of nicotine at LOD level $(0.2 \mathrm{ng} / \mathrm{mL})$ for the four species (Figure 2).

\subsection{Insect visitor behavior and survival}

\subsubsection{Abundance and diversity of visitors}

Diverse visitors, including honeybees, bumblebees, and syrphids, were observed on the four Tilia species. Honeybees were the main insect visitors except for $T$. $\times$ europaea $\left(\chi^{2}=165.69 ; \quad \mathrm{ddl}=6 ; p\right.$ value $<0.0001 ;$ Table IV). 
Table I. Phytosterols $(\mu \mathrm{g} / \mathrm{mg})$ and amino acids $(\mu \mathrm{g} / \mathrm{mg})$ in pollen of the four studied Tilia species $(N=3$ per species and analysis).

\begin{tabular}{|c|c|c|c|c|c|}
\hline Compounds & T. cordata & T. platyphyllos & T. tomentosa & T. $\times$ europaea & ANOVA \\
\hline \multicolumn{6}{|c|}{ Phytosterols } \\
\hline Cholesterol & $0.26 \pm 0.15 \mathrm{a}$ & $0.18 \pm 0.06 \mathrm{ab}$ & $0.02 \pm 00.1 b$ & $0.12 \pm 0.06 \mathrm{ab}$ & $\begin{array}{l}F(3,8)=3.97 \\
p \text { value }=0.0528\end{array}$ \\
\hline Cholestenone & $0.05 \pm 0.02$ & $0.01 \pm 0.01$ & $0.09 \pm 0.08$ & $0.01 \pm 0.01$ & $\begin{array}{l}F(3,8)=3.44 \\
p \text { value }=0.0719\end{array}$ \\
\hline Desmosterol & $0.02 \pm 0.02$ & $0.06 \pm 0.0 .5$ & $0.04 \pm 0.01$ & $0.03 \pm 0.0$ & $\begin{array}{l}F(3,8)=2.01 \\
p \text { value }=0.1915\end{array}$ \\
\hline $\begin{array}{l}\text { 24-methylenecholesterol + } \\
\text { campesterol }\end{array}$ & $0.24 \pm 0.08 \mathrm{a}$ & $0.01 \pm 0.01 b$ & $0.23 \pm 0.02 \mathrm{a}$ & $0.33 \pm 0.10 \mathrm{a}$ & $\begin{array}{l}F(3,8)=12.97 \\
p \text { value }=0.0019\end{array}$ \\
\hline Stigmasterol & $0.13 \pm 0.02$ & $0.15 \pm 0.02$ & $0.13 \pm 0.01$ & $0.12 \pm 0.03$ & $\begin{array}{l}F(3,8)=1.27 \\
p \text { value }=0.3482\end{array}$ \\
\hline D5-avesterol & $1.16 \pm 0.21$ & $0.76 \pm 0.13$ & $0.93 \pm 0.05$ & $0.87 \pm 0.29$ & $\begin{array}{l}F(3,8)=2.34 \\
p \text { value }=0.1499\end{array}$ \\
\hline D7-stigmasterol & $0.06 \pm 0.07$ & $0.09 \pm 0.09$ & $0.01 \pm 0.01$ & $0.01 \pm 0.01$ & $\begin{array}{l}F(3,8)=1.38 \\
p \text { value }=0.3182\end{array}$ \\
\hline D7-avenasterol & $0.10 \pm 0.06 \mathrm{~b}$ & $1.44 \pm 039 \mathrm{a}$ & $0.11 \pm 0.02 \mathrm{~b}$ & $0.56 \pm 0.17 \mathrm{~b}$ & $\begin{array}{l}F(3,8)=25.35 \\
p \text { value }=0.0002\end{array}$ \\
\hline B-sitosterol & $2.37 \pm 0.50$ & $2.00 \pm 0.22$ & $3.04 \pm 0.27$ & $2.06 \pm 0.62$ & $\begin{array}{l}F(3,8)=3.56 \\
p \text { value }=0.0669\end{array}$ \\
\hline \multicolumn{6}{|l|}{ Amino acids } \\
\hline Alanine & $11.66 \pm 0.65 \mathrm{c}$ & $18.60 \pm 0.50 \mathrm{a}$ & $10.75 \pm 0.30 \mathrm{c}$ & $13.25 \pm 0.42 b$ & $F(3,8)=157.80$ \\
\hline Arginine & $13.43 \pm 0.93 b$ & $15.64 \pm 0.36 \mathrm{a}$ & $10.91 \pm 0.31 \mathrm{c}$ & $13.81 \pm 0.51 b$ & $\begin{array}{l}F(3,8)=33.56 \\
p \text { value }<0.0001\end{array}$ \\
\hline Asparagine & $26.60 \pm 1.17 b c$ & $43.97 \pm 1.02 \mathrm{a}$ & $25.34 \pm 055 \mathrm{c}$ & $28.34 \pm 0.83 b$ & $\begin{array}{l}F(3,8)=266.41 \\
p \text { value }<0.0001\end{array}$ \\
\hline Cysteine & $2.47 \pm 0.63 \mathrm{a}$ & $0.02 \pm 0.04 \mathrm{c}$ & $1.56 \pm 0.06 \mathrm{~b}$ & $2.18 \pm 0.10 \mathrm{ab}$ & $\begin{array}{l}F(3,8)=34.73 \\
p \text { value }<0.0001\end{array}$ \\
\hline Glutamine & $28.53 \pm 1.49 b$ & $43.57 \pm 1.18 \mathrm{a}$ & $24.48 \pm 0.60 \mathrm{c}$ & $29.60 \pm 0.98 b$ & $\begin{array}{l}F(3,8)=168.36 \\
p \text { value }<0.0001\end{array}$ \\
\hline Glycine & $10.71 \pm 0.56 \mathrm{c}$ & $16.63 \pm 0.51 \mathrm{a}$ & $9.99 \pm 0.26 \mathrm{c}$ & $12.52 \pm 0.39 b$ & $\begin{array}{l}F(3,8)=132.37 \\
p \text { value }<0.0001\end{array}$ \\
\hline Histidine & $9.13 \pm 0.48 b$ & $10.77 \pm 0.33 \mathrm{a}$ & $8.24 \pm 0.25 b$ & $11.05 \pm 0.37 \mathrm{a}$ & $\begin{array}{l}F(3,8)=40.29 \\
p \text { value }<0.0001\end{array}$ \\
\hline Isoleucine & $12.63 \pm 0.68 \mathrm{c}$ & $17.20 \pm 0.49 \mathrm{a}$ & $10.84 \pm 0.33 \mathrm{~d}$ & $15.59 \pm 0.51 b$ & $\begin{array}{l}F(3,8)=91.21 \\
p \text { value }<0.0001\end{array}$ \\
\hline Leucine & $18.72 \pm 0.96 \mathrm{~b}$ & $25.24 \pm 0.79 \mathrm{a}$ & $15.67 \pm 0.43 \mathrm{c}$ & $19.65 \pm 0.62 b$ & $\begin{array}{l}F(3,8)=90.60 \\
p \text { value }<0.0001\end{array}$ \\
\hline Lysine & $18.29 \pm 0.91 \mathrm{~b}$ & $24.05 \pm 0.36 \mathrm{a}$ & $15.68 \pm 0.39 \mathrm{c}$ & $18.83 \pm 0.59 b$ & $\begin{array}{l}F(3,8)=101.06 \\
p \text { value }<0.0001\end{array}$ \\
\hline Methionine & $6.83 \pm 0.38 \mathrm{a}$ & $0.66 \pm 0.31 \mathrm{c}$ & $5.61 \pm 0.20 \mathrm{~b}$ & $7.37 \pm 0.35 \mathrm{a}$ & $\begin{array}{l}F(3,8)=275.65 \\
p \text { value }<0.0001\end{array}$ \\
\hline Phenylalanine & $13.29 \pm 0.73 a$ & $9.42 \pm 0.03 c$ & $10.76 \pm 0.35 b$ & $14.27 \pm 0.51 \mathrm{a}$ & $\begin{array}{l}F(3,8)=65.48 \\
p \text { value }<0.0001\end{array}$ \\
\hline Proline & $22.12 \pm 1.05 b$ & $24.59 \pm 0.65 \mathrm{a}$ & $16.63 \pm 0.75 \mathrm{c}$ & $21.68 \pm 0.61 b$ & $\begin{array}{l}F(3,8)=53.97 \\
p \text { value }<0.0001\end{array}$ \\
\hline
\end{tabular}


Table I (continued)

\begin{tabular}{|c|c|c|c|c|c|}
\hline Compounds & T. cordata & T. platyphyllos & T. tomentosa & T. $\times$ europaea & ANOVA \\
\hline Serine & $13.41 \pm 0.68 \mathrm{bc}$ & $20.40 \pm 0.57 \mathrm{a}$ & $12.19 \pm 0.31 \mathrm{c}$ & $14.79 \pm 0.49 b$ & $\begin{array}{l}F(3,8)=140.89 \\
p \text { value }<0.0001\end{array}$ \\
\hline Threonine & $11.69 \pm 0.66 b$ & $15.88 \pm 0.44 \mathrm{a}$ & $10.24 \pm 0.29 \mathrm{c}$ & $12.41 \pm 0.41 b$ & $\begin{array}{l}F(3,8)=78.08 \\
p \text { value }<0.0001\end{array}$ \\
\hline Tyrosine & $9.93 \pm 0.79 b$ & $18.00 \pm 0.73 \mathrm{a}$ & $8.05 \pm 0.25 c$ & $10.35 \pm 0.39 b$ & $\begin{array}{l}F(3,8)=167.85 \\
p \text { value }<0.0001\end{array}$ \\
\hline Valine & $13.67 \pm 0.65 b c$ & $17.49 \pm 0.58 \mathrm{a}$ & $12.40 \pm 0.27 \mathrm{c}$ & $14.89 \pm 0.45 b$ & $\begin{array}{l}F(3,8)=54.99 \\
p \text { value }<0.0001\end{array}$ \\
\hline
\end{tabular}

\subsubsection{Observed dead insects}

Very few dead insects were observed under the flowering trees, with only two Apis mellifera individuals, two Bombus terrestris morphotype individuals, one Lasioglossum marginatum, and three Syrphidae (Eupeodes latifasciatus and Episyrphys balteatus) in a total of $80 \mathrm{~h}(20 \mathrm{~h}$ per tree species). Only one dead honeybee was found under Tilia tomentosa, showing no increased mortality for this late flowering Tilia species.

\subsubsection{Bumblebee survival}

Bumblebee workers fed exclusively on flowers of $T$. cordata or of $T$. tomentosa survived even well than bumblebees with no access to Tilia flowers (Figure 3). After 6 days per experiment, the bumblebee mortality ranged from 5 to 12 individuals (out of 30 for each experiment).

\section{DISCUSSION}

\subsection{Are nectar and pollen offered in similar quantities and compositions?}

Our four studied species differ in both the quantity and the composition of floral resources. Tilia tomentosa offered more flowers per cubic meter, more pollen grains per flower, and more nectar than the other studied Tilia species. Total sugar content in Tilia nectars ranged from $0.24 \mathrm{mg}$ per flower ( $T$. tomentosa) to $0.06-$ $0.10 \mathrm{mg}$ (three other species). Other authors reported similar sugar volumes and concentrations (Käpylä 1978; Pigott 1991; Krasenbrink et al. 1994; Baal et al. 1994; Gašić et al. 2014; Somme et al. 2016; Argoti 2016).

In pollen, a high nitrogen content, particularly with a protein content higher than $20 \%$ $\mathrm{dw}$, is positively correlated with the development of bee larvae (Tasei and Aupinel 2008). Pollen from our studied Tilia trees contained more than $20 \%$ total amino acids and all

Table II. Minor sugar concentrations in nectar of the four studied Tilia species.

\begin{tabular}{|c|c|c|c|c|c|}
\hline Sugars & T. cordata & T. platyphyllos & T. tomentosa & T. $\times$ europaea & ANOVA \\
\hline Mannose $(\mathrm{ng} / \mu \mathrm{L})$ & $<$ LOD & $<\mathrm{LOD}$ & $<\mathrm{LOD}$ & $<\mathrm{LOD}$ & \\
\hline Galactose $(\mathrm{ng} / \mu \mathrm{L})$ & $9.3 \pm 15.3$ & $6.3 \pm 9.3$ & $<\mathrm{LOD}$ & $2.7 \pm 0$ & $\begin{array}{l}F(3,6)=0.44 \\
p \text { value }=0.7337\end{array}$ \\
\hline Myo-inositol (ng/ $\mu \mathrm{L})$ & $7.2 \pm 11.7$ & $1.0 \pm 0.3$ & $1.8 \pm 0.5$ & $0.6 \pm 0$ & $\begin{array}{l}F(3,6)=0.55 \\
p \text { value }=0.6689\end{array}$ \\
\hline Raffinose (ng/ $\mu \mathrm{L})$ & $<\mathrm{LOD}$ & $0.07 \pm 0.13$ & $0.12 \pm 0.21$ & $<\mathrm{LOD}$ & $\begin{array}{l}F(3,6)=0.44 \\
p \text { value }=0.7354\end{array}$ \\
\hline
\end{tabular}


Table III. Extraction recoveries of SPE cartridges (concentrations in $\mathrm{ng} / \mathrm{mL}$ ) obtained for four solutions of different concentrations of nicotine spiked in Impatiens nectar passed through SPE cartridges $(m=4, n=1, k=2)$. The concentrations after SPE were calculated with the calibration curve.

\begin{tabular}{|c|c|c|c|c|}
\hline \multicolumn{2}{|c|}{$\begin{array}{l}\text { Nicotine spiked } \\
\text { concentration before SPE }\end{array}$} & \multirow{2}{*}{$\begin{array}{l}\begin{array}{l}\text { Nicotine calculated } \\
\text { concentration after SPE }\end{array} \\
0.469\end{array}$} & \multirow{2}{*}{$\begin{array}{l}\begin{array}{l}\text { Average nicotine } \\
\text { concentration after SPE }\end{array} \\
0.475\end{array}$} & \multirow{2}{*}{$\begin{array}{l}\text { Recovery (\%) } \\
95.00\end{array}$} \\
\hline 0.5 & 0.481 & & & \\
\hline 1.0 & 0.954 & 0.967 & 0.961 & 96.10 \\
\hline 10.0 & 9.355 & 9.772 & 9.564 & 95.64 \\
\hline 25.0 & 23.471 & 23.806 & 23.639 & 94.55 \\
\hline
\end{tabular}

essential amino acids, which confirm their potential utility as pollen source (Fornoff et al. 2017). Furthermore, as pollen presented a balanced amino acid content, they are attractive to pollen-collecting insects (Somme et al. 2015). Pollen of Tilia trees could also be source of phytosterols as bumblebees collect pollen with both high amino acid and sterol contents (Vaudo et al. 2015).

\subsection{Do the nectars contain mannose or nicotine?}

No trace of mannose or nicotine has been detected in our nectar samples, whatever the studied species. Mannose and nicotine concentrations in the four species nectars were $<1.44 \mathrm{ng} / \mu \mathrm{L}$ and $<$ $0.2 \mathrm{ng} / \mathrm{mL}$ respectively. The absence of mannose contradicted the results obtained by other authors

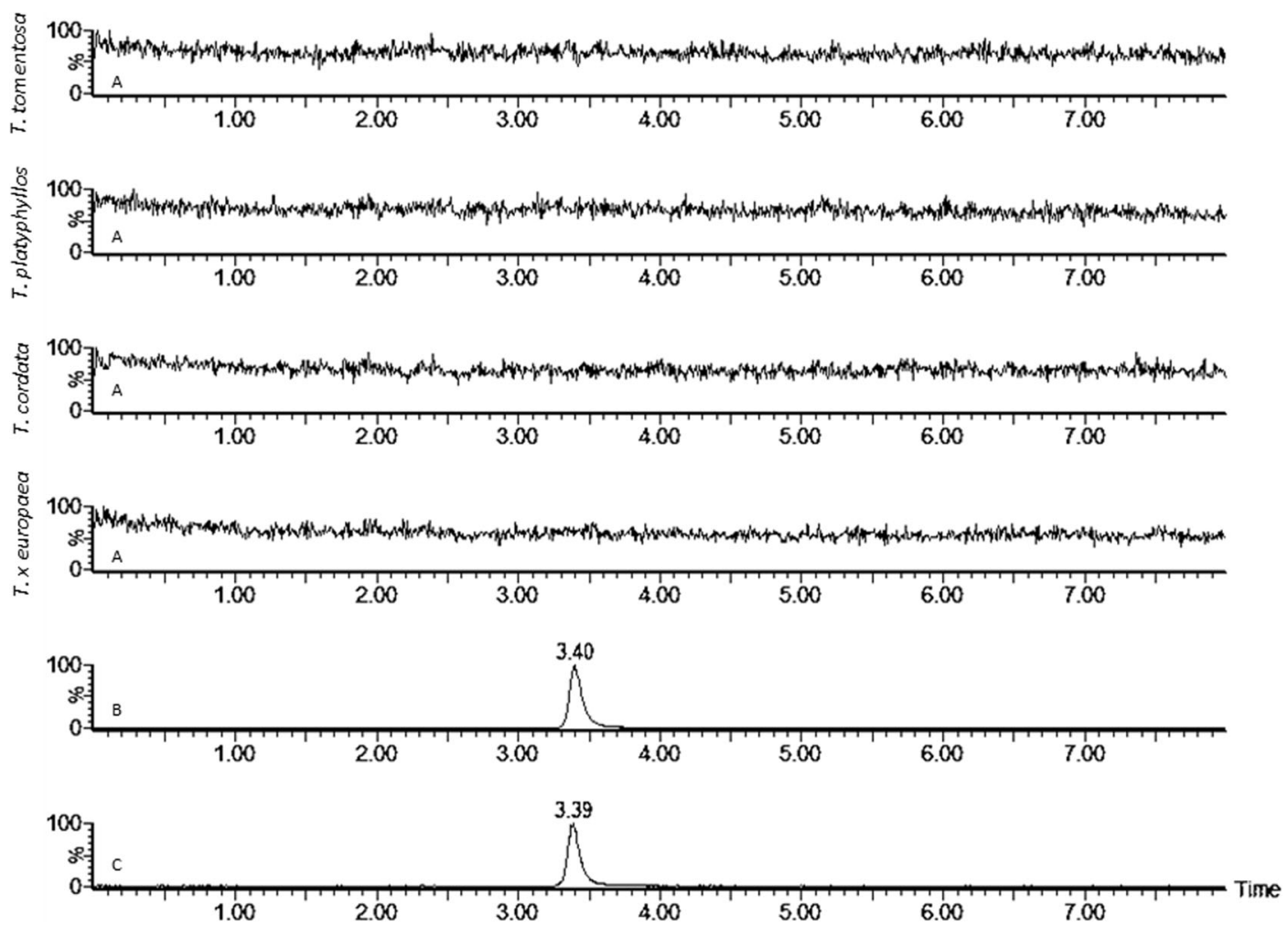

Figure 2. Chromatograms obtained after the SPE-LC-MS analyses of the nectars from the four studied species. a MRM for nicotine. b. MRM for D4-nicotine. $\mathbf{c}$ Total ion current. Chromatograms $\mathbf{b}$ and $\mathbf{c}$ are similar for the four species. 
Table IV. Insect visitors observed on the four studied Tilia tree species at Louvain-la-Neuve, June and July 2016, on 70 sessions of $15 \mathrm{~min}$ in total ( $N=$ total number of visitors observed per species).

\begin{tabular}{lcccc}
\hline Insect visitors (\%) & T. cordata & T. platyphyllos & T. tomentosa & T. $\times$ europaea \\
\hline $\mathrm{N}$ visitors & 99 & 104 & 322 & 14 \\
Honeybees $^{\mathrm{a}}$ & 79.8 & 55.8 & 87.3 & 28.6 \\
Bumblebees $^{\mathrm{b}}$ & 6.1 & 27.9 & 0.6 & 71.4 \\
Syrphids $^{\mathrm{c}}$ & 14.1 & 16.3 & 12.1 & 0 \\
\hline
\end{tabular}

${ }^{a}$ Honeybees (Hymenoptera, Apidae) corresponded to Apis mellifera

${ }^{\mathrm{b}}$ Bumblebees (Hymenoptera, Apidae) were represented by Bombus terrestris morphotype and B. hypnorum morphotype

${ }^{\mathrm{c}}$ Syrphids (Diptera) included Eupeodes latifasciatus, Episyrphus balteatus, Eristalis arbustorum, E. intricaria, E. tenax, Helophilus trivittatus, and Syritta pipiens

(Madel 1977; Argoti 2016). Several studies have stated that mannose is toxic and present in the nectar without chemically identifying its presence in Tilia nectar (Wykes 1952; Pigott 1991; Pawlikowski 2010). Madel (1977) found mannose in the nectar of $T$. tomentosa using paper chromatography. However, based on more precise techniques, such as gas chromatrography, Baal et al. (1994) or Gašić et al. (2014) failed to detect mannose in the nectar or even in other parts of the flowers.

The assumption that Tilia nectar contains mannose potentially originates from a time when modern analytical methods had not yet been used (Argoti 2016; VKM 2017).

Contrarily to our results, trace amounts of nicotine have been indicated to occur in Tilia nectar
(Naef et al. 2004). Nevertheless, Singaravelan et al. (2006) concluded that honeybees can cope with naturally occurring concentrations of nicotine, even when consumed in large quantities (up to $50 \mathrm{ng} / \mu \mathrm{L}$ ). Moreover, bumblebees may even recover if fed with nectar from $T$. tomentosa tree shortly after falling to the ground (Surholt et al. 1992). These studies question the toxicity for bumblebees of secondary metabolites in Tilia nectar. We can therefore conclude that no toxic compounds have been yet detected in Tilia nectar. In the same order, toxicity of the pollen or of the honeydew seems unlikely (VKM 2017). However, toxicity tests of the volatile secondary metabolites found in nectar are still lacking (VKM 2017).

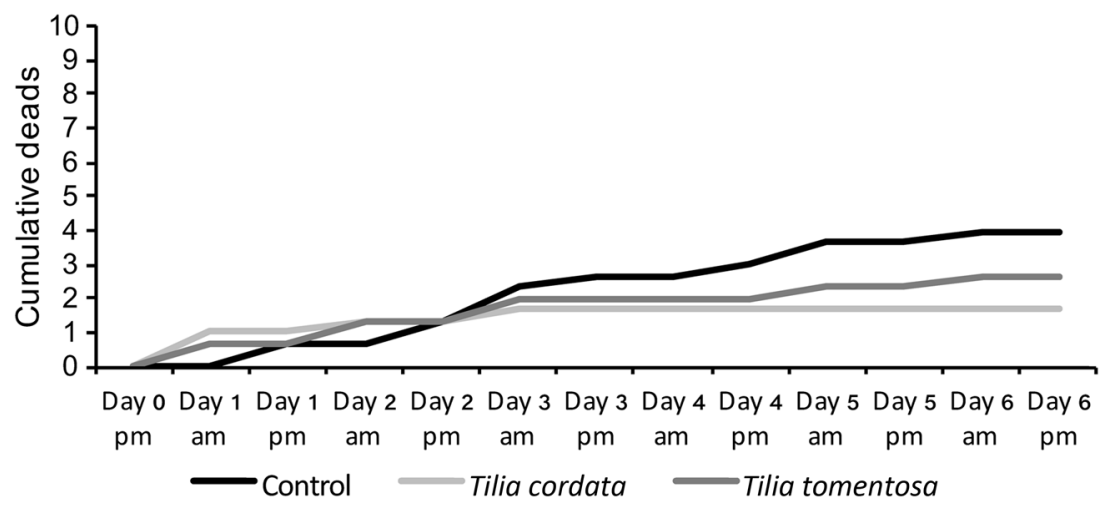

Figure 3. Cumulative dead Bombus over ten individuals under each of the three mosquito nets and from three different hives (three experiments): control with bumblebees fed with pollen and Biogluc ad libitum and access to branches of Tilia spp. without any flowers (black line), with Tilia cordata flowers (pale gray line), and with Tilia tomentosa flowers (dark gray line). 


\subsection{Do the different Tilia species attract similar insect visitors?}

As in other studies, even in a few hours, we observed diverse visitors on Tilia species, including honeybees, bumblebees, and syrphids. Even if their numbers and proportions depend on the activity of the surrounding apiaries, honeybees are considered numerous and constant on Tilia trees (Knuth 1908; Anderson 1976; Pigott 1991; Illies and Mühlen 2007; Pawlikowski 2010). Our observed bumblebees, Bombus terrestris and B. hypnorum, have already been determined in other sites (Knuth 1908; Pigott 1991; Illies and Mühlen 2007; Pawlikowski 2010). Bumblebee fidelity to Tilia pollen has been assessed as much as $70 \%$ of the bee pollen loads contained Tilia pollen (WeryszkoChmielewska and Sadowka 2010).

\subsection{Do bumblebees present any mortality?}

We did not detect any particular mortality among the bumblebee workers fed only on Tilia flowers. In fact, several authors did not mention any death during their observations (Knuth 1908; Free 1970) or only reported few bees crawling (Illies and Mühlen 2007). In our study site, spring and summer climatic conditions in 2016 (May to August) were considered normal with a mean temperature about $16{ }^{\circ} \mathrm{C}$, and after a rainy spring (78.3 mm in May), summer months did not present any pluviometry deficit (55 $\mathrm{mm}$ in June and July; Royal Meteorological Institute Belgium 2016). We were not able to test in natura the mortality of bees under water deficit evoked by Crane (1977).

Bees are prone to starvation if they fail to find sufficient nectar resources during a foraging bout (Baal et al. 1994; Surholt and Baal 1995; Illies 2016; VKM 2017; Koch and Stevenson 2017). Illies and Mühlen (2007) observed that the number of dead bumblebees increased throughout the season and reached the maximum at the end of the flowering period of $T$. tomentosa. As 3-4 mg of nectar can be produced by a single flower, and this amount will be replaced on successive days (Anderson 1976), it seems curious that such high resource can induce bee starvation. Tilia trees produce more nectar than the other planted urban trees (Somme et al. 2016). In consequence, more detailed monitoring of nectar availability related to bee death is needed in order to assess this hypothesis.

A last hypothesis posits a natural death of bees (VKM 2017). Tilia trees are flowering in summer, coinciding with a peak in the development of the colonies. As bumblebee individuals have a short lifetime expectancy, the mortality is high. Mühlen et al. (Mühlen et al. 1992, 1994) found that the majority of the dead bumblebees were workers, which can confirm this hypothesis. As bees tend to accumulate to forage on Tilia trees, the deaths observed might be a result of the patchy distribution of workers (VKM 2017). As Tilia trees are often planted in parks or paved sidewalks with short vegetation or bare ground, dead bees are more easily visible there than under other vegetation. Indeed, if comparable floral resource hotspots exist, they should be associated with deaths to a similar extent. To our knowledge, such comparisons of numbers of dead bees are still lacking. More information about the natural death hypothesis is needed.

\section{ACKNOWLEDGMENTS}

We are grateful to W. Stinglhamber, P. Lhoir, and A. Lanotte for field assistance and C. Tinel, H. Dailly, and I. Van de Vreken for chemical analyses. We thank B. Wathelet (Industrial Biological Chemistry Unit, University of Liège), G. Lognay (Laboratory of Analytical Chemistry, University of Liège), and D. Michez (Laboratory of Zoology, University of Mons) for granting access to their lab. LC-MS analyses for nicotine were realized at the MASSMET Platform of LDRI-UCL. Thanks to J. Mach for language improvement, C. Mayer for German translation, and two anonymous reviewers for their valuable comments on the manuscript.

\section{AUTHOR CONTRIBUTIONS}

ALJ, MQ, JQL, and MFH conceived this research and designed the experiments; WS, MQ, PO, and LM performed experiments and analysis; ALJ, MQ, JQL, and MFH wrote the paper and participated in the revisions of it. All authors contributed critically to the drafts and approved the final manuscript. 


\section{COMPLIANCE WITH ETHICAL STANDARDS}

Conflict of interest The authors declare that they have no conflict of interest.

Tilia: ressources toxiques ou précieuses pour les pollinisateurs?

tilleuls / Tilia tomentosa / nicotine / mannose / abeilles / nectar / pollen

\section{Lindenbäume: Giftige oder wertvolle Resourcen für Bestäuber?}

\section{Lindenbäume / Tilia tomentosa / Nikotin/ Mannose / Bienen / Nektar / Pollen}

\section{REFERENCES}

Abdallah, I.A., Hammell, D.C., Stinchcomb, A.L., Hassan, H.E. (2016) A fully validated 1C-MS/ MS method for simultaneous determination of nicotine and its metabolite cotinine in human serum and its application to a pharmacokinetic study after using nicotine transdermal delivery systems with standard heat application in adult smokers. J. Chromat. 1020, 67-77

Anderson, G.J. (1976) The pollination biology of Tilia. Am. J. Bot. 63, 1203-1212

Argoti, A.G. (2016) Abejas asociadas a los arboles de Linden (Tilia spp.) y sus susceptibilidad a azucares toxicos presentes en el nectar. Master degree dissertation. University of Oregon. Retrieved on http://repositorio. educacionsuperior.gob.ec/handle/28000/2675

Arnold, H., Seitz, U., Löhr, G.W. (1974) Die Hexokinase und die Mannosetoxizität der Biene. Hoppe-Seyler's Physiol. Chem. 335, 266272

Baal, T., Denker, B., Mühlen, W., Surholt, B. (1994) Die Ursachen des Massensterbens von Hummeln unter spätblühenden Linden. Nat. Landsch. 69, 412-418

Baker, H.G. (1977) Non-sugar chemical constituents of nectar. Apidologie 8, 349-356

Baracchi, D., Brown, M.J.F., Chittka, L. (2015) Weak and contradictory effects of selfmedication with nectar nicotine by parasitized bumblebees. F1000Research 4, 73 https://doi.org/10.12688/f1000research.6262.3

Bates, A.J., Sadler, J.P., Fairbrass, A.J., Falk, S.J., Hale, J.D., Matthews, T.J. (2011) Changing bee and hoverfly pollinator assemblages along an urban-rural gradient. PloS ONE 6, e23459

Crane, E. (1977) Dead bees under lime trees. Bee World $\mathbf{5 8}, 129-130$
Detzel, A., Wink, M. (1993) Attraction, deterrence or intoxication of bees (Apis mellifera) by plant allelochemicals. Chemoecology 4, 8-18

EMAE (European Medicines Agency (2011) Guideline for bioanalytical method validation. EMAE/CHMP/EWP/ 192217/2009, 23 pp.

Fornoff, F., Klein, A.M., Hartig, F., Benadi, G., Venjakob, C., Schaefer, H.M., Ebeling, A. (2017) Functional flower traits and their diversity drive pollinator visitation. Oikos 126, 1020-1030

Free, J.B. (1970) The flower constancy of bumblebees. J. Anim. Ecol. 39 (2), 395-402

Gašić, U., Šikoparija, B., Tosti, T., Trifković, J., Milojković-Opsenica, D., Natić, M., Tešić, Ž. (2014) Phytochemical fingerprints of lime honey collected in Serbia. J AOAC Intern. 97 (5), 1259-1267

Geissler, G., Steche, W. (1962) Steche Natürliche Trachten als Ursache für Vergiftungserscheinungen bei Bienen und Hummeln. Zeitschrift für Bienenforschung 6, 77-92

Goulson, D., Nicholis, E., Botias, C., Rotheray, E.L. (2015) Bee declines driven by combined stress from parasites, pesticides, and lack of flowers. Science 347 (6229), 1435-1443

Hunter, M.R., Hunter, M.D. (2008) Designing for conservation of insects in the built environment. Insect Cons. Div. 1, 189-196

Illies, I. (2016) Linden als Bienenweide. LWF Wissen 78 , 66-68

Illies, I., Mühlen, W. (2007) The foraging behaviour of honeybees and bumblebees on late blooming lime trees (Tilia spec.) (Hymenoptera: Apidae). Entomol. Gener. 30, 155-165

Ivanov, P., Loghin, C., Enescu, C.M. (2014) Morphological differentiation between Romanian lime species (Tilia spp.): a case study. Bull. Transilvania Univ. Brasov. 7 (56), 21-25

Käpylä, M. (1978) Amount and type of nectar sugar in some wild flowers in Finland. Ann. Bot. Fennici 15, 85-88

Kessler, D., Diezel, C., Baldwin, I.T. (2010) Changing pollinators as a means of escaping herbivores. Current Biol. 20, 237-242

Knuth, P. (1908) Handbook of flower pollination. Oxford Clarendon Press, Vol 2, pp 213-214.

Koch, H., Stevenson, P.C. (2017) Do linden trees kill bees? Reviewing the causes of bee deaths on silver linden (Tilia tomentosa). Biol. Lett. 13, 20170484

Krasenbrink, A., Popp, M., Denker, B. (1994) Nektarzusammensetzung von Tilia tomentosa (Moench) und anderen Lindenarten/-hybriden. Z Okologie Naturschutz 3, 237-242

Madel, G. (1977) Poisoning of bumble bees by nectar of the silver lime Tilia tomentosa. Bonner. Zool. Beitrage 28, 149-154

McKinney, M.L. (2008) Effects of urbanization on species richness: A review of plants and animals. Urban Ecosyst. 11, 161-176 
Mühlen, W., Riedel, V., Baal, T., Denker, B., Surholt, B. (1992) The mortality rate of insects foraging on late blooming lime trees. Analysis with regard to species, caste and sex. Apidologie 23, 329-331

Mühlen, W., Riedel, V., Baal, T., Surholt, B. (1994) Insektensterben unter blühenden Linden. Nat. Landsch. 69, 95-100

Naef, R.., Jaquier, A., Velluz, A., Bachofen, B. (2004) From the linden flower to linden honey-volatile constituents of linden nectar, and extract of bee-stomach and ripe honey. Chem. Biodiv. 1, 1870-1879

Nicolson, S.W. (2011) Bee food: the chemistry and nutritional value of nectar, pollen and mixtures of the two. African Zool. 46, 197-204

Pawlikowski, T. (2010) Pollination activity of bees (Apoidea: Apiformes) visiting the flowers of Tilia cordata Mill. and Tilia tomentosa Moench in an urban environment. J. Apicult. Sci. 54, 73-79

Petanidou, T. (2005) Sugars in Mediterranean floral nectars: an ecological and evolutionary approach. J. Chem. Ecol. 31, 1065-1087

Pigott, C.D. (1991) Tilia cordata. J. Ecol. 79 (4), 11471207

Pigott, C. (2012) Lime-trees and basswoods: a biological monograph of the genus Tilia. Cambridge Univ Press, Cambridge

Radoglou, K., Dobrowolska, D., Spyroglou, G., Nicolescu, V.N. (2009) A review on the ecology and silviculture of limes (Tilia cordata Mill., Tilia platyphyllos Scop. and Tilia tomentosa Moench.) in Europe. Die Bodenkultur 60 (3), 9-19

Singaravelan, N., Inbar, M., Ne'eman, G., Distl, M., Wink, M. (2006) The effects of nectar-nicotine on colony fitness of caged honeybees. J. Chem. Ecol. 32, 49-59

Somme, L., Vanderplanck, M., Michez, D., Lombaerde, I., Moerman, R, Wathelet, B., Wattiez, R.' Lognay, G, Jacquemart, A.L. (2015) Pollen and nectar quality drive the major and minor floral choices of bumble bees. Apidologie 46, 92-106

Somme, L., Moquet, L., Quinet, M., Vanderplanck, M., Michez, D., Lognay, G., Wathelet, B., Jacquemart, A.L (2016) Food in a row: urban trees offer valuable floral resources to pollinating insects. Urban Ecosyst. 19, 1149-1161.

Surholt, B, Baal, T. (1995) Die Bedeutung blühender Silberlinder für Insekten im Hochsommer. Nat. Landsch. 70, 252-258
Surholt, B, Denker, B., Baal, T., Mühlen, W. (1992) Is the nectar of silver lime trees toxic to bumblebees? Videorecorded outdoor experiments. Apidologie 23, 335-337

Tadmor-Melamed, H., Markman, S., Arieli, A. Distl, M., Wink, M., Izhaki, I. (2004) Limited ability of Palestine sunbirds Nectarinia osea to cope with pyridine alkaloids in nectar of tree tabacco Nicotiana glauca. Funct. Ecol. 18, 844-850

Tasei, J.N., Aupinel, P. (2008) Nutritive value of 15 single pollens and pollen mixes tested on larvae produced by bumble bee workers (Bombus terrestris, Hymenoptera: Apidae). Apidologie 39, 397-409

Tiedeken, E.J., Stout, J.C., Stevenson, P.C., Wright, G.A. (2014) Bumblebees are not deterred by ecologically relevant concentrations of nectar toxins. J. Exp. Biol. 217, 1620-1625

Tutin, T.G., Heywood, V.H., Burges, N.A., et al. (1968) Flora Europaea. Volume II. Rosaceae to Umbelliferae. pp 247-248. Cambridge University Press, Cambridge.

Vanderplanck, M., Michez, D., Vancraenenbroeck, S., Lognay, G. (2011) Microquantitative method for analysis of sterol levels in honeybees and their pollen loads. Anal. Lett. 44, 1807-1820

Vanderplanck, M., Leroy, B., Wathelet, B., Wattiez, R., Michez, D. (2014) Standardized protocol to evaluate pollen polypeptides as bee food source. Apidologie 45, 192-204

Vaudo, A.D., Tooker, J.F., Grozinger, C.M., Patch, H.M. (2015) Bee nutrition and floral resource restoration. Curr. Opin. Insect Sci. 10, 133-141

Villette, C., Berna, A., Compagnon, V., Schaller, H. (2015) Plant sterol diversity in pollen from Angiosperms. Lipids 50,749-760

VKM (2017) Assessment of the potential connection between Tilia trees and bumblebee death. Scientific Opinion on the Panel on Alien Organisms and Trade in Endangered species of the Norwegian Scientific Committee for Food Safety. 15, 46 p. Oslo, Norway

Weiner, C.N., Hilpert, A., Werner, M., Linsenmair, K.E., Blüthgen, N. (2010) Pollen amino acids and flower specialisation in solitary bees. Apidologie 41,476-487

Weryszko-Chmielewska, E., Sadowka, D.A. (2010) The phenology of flowering and pollen release in four species of linden (Tilia L.). J. Apic. Sci. 54, 99-107

Wykes, G.R. (1952) An investigation of the sugars present in the nectar of flowers of various species. New Phytol. $\mathbf{5 1}, 210-215$ 